\title{
SocArXiv
}

\section{The Persistence of Gender Segregation at Work}

\author{
Philip N. Cohen \\ University of Maryland, College Park
}

\begin{abstract}
Occupational gender segregation remains one of the defining elements of gender inequality in modern societies. Recent trends for the United States show that occupational segregation remains high, and did not substantially decline in the decade of the 2000s for the first time since 1960. Men and women work in different occupations because of a combination of forces, including culturally-defined choices by workers themselves, discrimination by employers, and differences in skill levels and qualities. Research has shown that occupational segregation is an important aspect of gender inequality in earnings, and contributes to other forms of inequality as well. The prospects for reducing gender segregation in the short term appear slim, based on the weak effects of educational attainment, cultural attitudes, and state intervention in the current period.
\end{abstract}

Keywords: gender segregation, occupational segregation, gender inequality.

\author{
Affiliation: \\ Philip N. Cohen \\ University of Maryland, College Park \\ E-mail: pnc@umd.edu \\ URL: philipncohen.com
}

\section{SocArXiv.org}

For info, visit the SocOpen blog:

SocArXiv.org

SocOpen.org

Preprint: Sociology Compass 2013711 889-899 


\section{Introduction}

Nothing defines the nature of gender in a society more than the tendency of men and women to do different work. In both paid and unpaid work, contemporary societies exhibit a remarkable level of differentiation between the tasks done by women and those done by men - the gender segregation of work. This basic feature of society has proven highly resilient in the face of dramatic social change in many other arenas, including the workplace, the family and the state (Geist \& Cohen 2011). However, variation in the pattern of segregation belies the common assumption that it is immutable (Yaish \& Stier 2009). Rather, although gender segregation is a universal aspect of gender inequality, the form that it takes reveals the nature of the gender system, and in theory it is no more inevitable than gender inequality itself (Charles \& Grusky 2004).

This review concerns gender segregation in the paid workplace, known as occupational or job segregation. As Kim Weeden (1998) has written, occupational segregation is at once a direct measure of inequality and a precursor to other forms of inequality associated with occupational status. Segregation is a lynchpin of gender inequality because it serves as a key site of gender differentiation and, in Barbara Reskin's phrase, "differentiation is the sine qua non of dominance systems” (1988:64). After discussing some issues of measurement, I provide a brief status update on the state of segregation in the United States. Second, I review recent research on its causes and consequences. In the last section, I offer some thoughts on the near future of gender segregation.

\section{How segregated are men and women at work?}

To describe the level of segregation between men and women, we need not only data on what jobs people do, but also a measure of the difference in the distribution of occupational positions. The issue of measurement has been debated extensively in the sociological literature, as different measures produce results with different implications (Charles and Grusky 2004). The primary distinction is between measures that identify the extent to which occupations are segregated versus those that identify the level of segregation among workers themselves. For example, if there are 10 jobs and only one of them has an equal share of men and women, one could say the other 9 jobs were segregated. However, if almost all of the workers are in that one integrated job, we could say that most workers work in an integrated job.

The most common measure of segregation is the index of dissimilarity. This measure reports what percentage of men, or women, would have to change occupations to make the gender distribution equal across all occupations (Duncan \& Duncan 1955). A simple variety on that measure, known as the size-standardized index of dissimilarity, treats each occupation as a single observation, rather than treating individual workers as the units of analysis. By that logic, for 
example, the gender composition of 4 million truck drivers would constitute one data point and 1 thousand blacksmiths would constitute another. A further variation constructs log-multiplicative models using gender ratios in each occupation, at which point the computations and assumptions become much more complex (Bridges 2003; Charles \& Grusky 1995).

Another important factor to consider in measuring segregation is the level of detail used. Researchers almost always find looking at the distribution of men and women in greater detail for example, differentiating between physicians as a general category versus pediatricians, surgeons (Ku 2011), or between public interest versus corporate lawyers (Kay \& Gorman 2008) - yields higher levels of segregation. The same is true if one can identify the specific geographic location of workers or the industry in which they work (Cohen and Huffman 2003; Roto and Wilson 2007). Even further, when researchers are able to look at specific workplaces, rather than occupations, a still greater degree of segregation emerges (Mctague, Stainback \& TomaskovicDevey 2010; Tomaskovic-Devey et al. 2006). Put another way, gender segregation persists within occupations, not just between them.

In the United States, the Census Bureau counts the occupations of workers according to a federal classification scheme that was overhauled in 2000 (making it impossible to make exact comparisons to earlier periods). Using that data on about 500 occupations for 2000 and 2010, including only workers employed full-year and full-time, I calculated the index of dissimilarity. ${ }^{1}$ Over the decade of the 2000s there was almost no change: the index of dissimilarity was 51.0\% in 2000, and for 2010 it was 50.1\%. ${ }^{2}$ That is the slowest progress toward integration of any decade since 1960, when segregation started a long trend downward (Cotter et al. 2004).

To get a better picture of this level of segregation, consider Figure 1 and Figure 2, which describe the data from 2010. The first shows the distribution of men and women in occupations grouped according to their gender composition. For example, the figure shows that the most common type of occupation for men is less than $10 \%$ female, with $26 \%$ of men working in such jobs. On the other hand, the most common location for women is in the $80-89 \%$ female range, where $20 \%$ of women work. The second figure shows the cumulative distributions of men and women, again including only full-time, year-round workers. Thus, each point on a line shows the percentage of workers in occupations at or below that level of female concentration. This allows us to see, for example, that the median occupation for men is $25 \%$ female. That is, half of men work in occupations with fewer women, and half work in occupations with more. On the other hand, the median occupation for women is $67 \%$ female.

\footnotetext{
${ }^{1}$ The 2000 data are from the tables supplemental to Weinberg (2004), using the 2000 Decennial Census; the 2010 data are from the Census Bureau's American Community Survey, extracted with the American Factfinder (factfinder2.census.gov).

${ }^{2}$ The size-standardized version of this measure is very similar: $52.2 \%$ in 2000 and $52.3 \%$ in 2010.
} 


\section{FIGURE 1}

\section{Distribution of men and women, by occupation percent female}

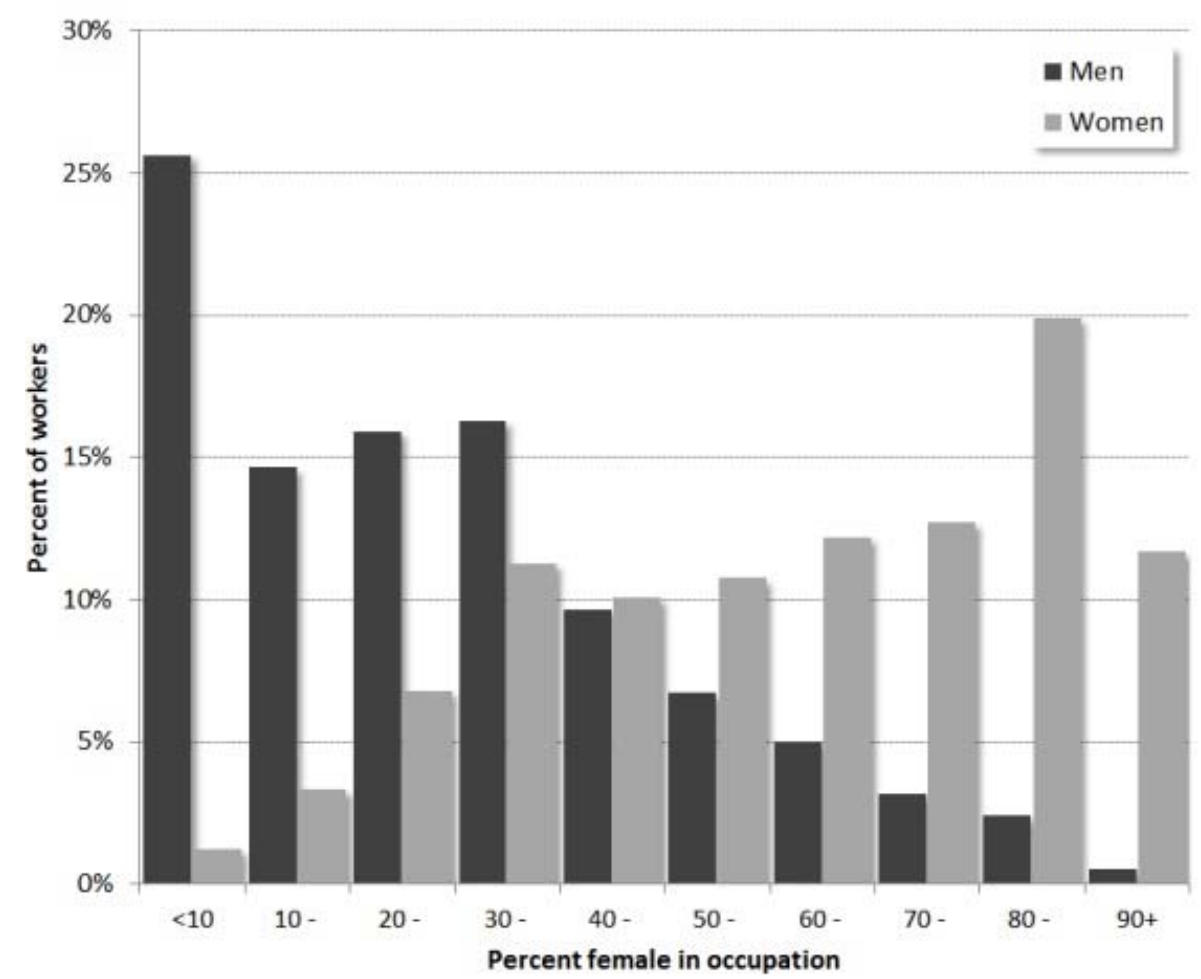

Note: Full-time, year-round workers. Source: U.S. Census Bureau, 2010 American Community Survey. 
FIGURE 2

Cumulative distributions of men and women, by percent female in occupation

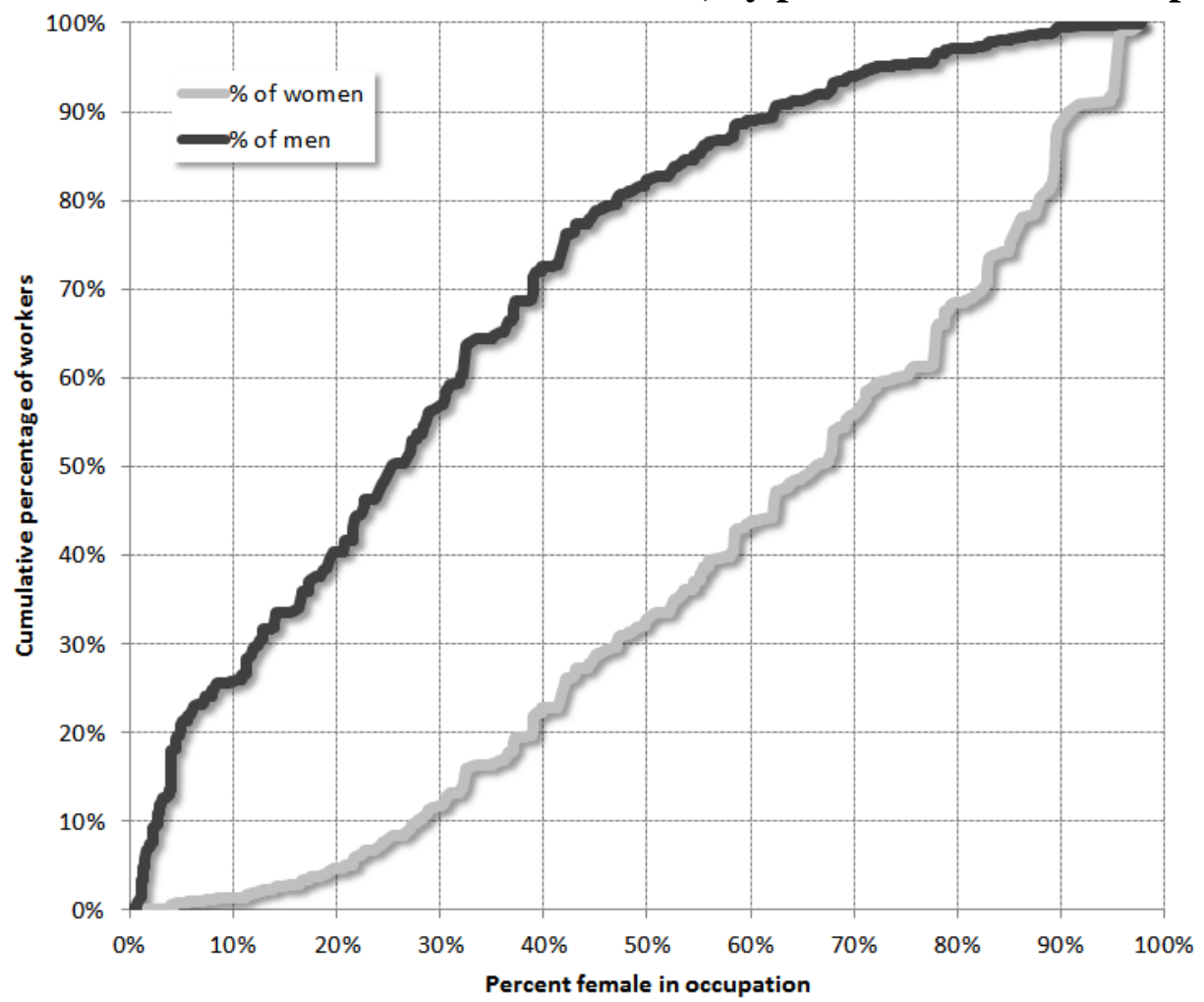

Note: Full-time, year-round workers. Source: U.S. Census Bureau, 2010 American Community Survey.

Finally, for a more detailed description of the occupations involved, Table 1 shows the 25 most common occupations for full-time, full-year workers in 2010, listed from those with the highest percentage of women to those with the highest percentage of men. The table also includes median earnings for men and women in each occupation. Thus we can see, for example, that the most gender-segregated occupations - secretaries (96\% female) and construction laborers (98\% male) are relatively low paid. On the other hand, the highest paid occupations on this list managers, lawyers and chief executives - are male-dominated but not completely segregated, in the range of $67 \%-78 \%$ male. This is consistent with the pattern observed in 2000 as well (Cotter et al. 2004).

\section{What are the causes of segregation?}

Preferences, choices and opportunities

Paula England (2010) has suggested that social change with regard to gender segregation is largely one-sided, as women seek access to male-dominated jobs more than the reverse - 
because female-dominated jobs are compensated less. Thus, changes in women's occupational distribution have been more pronounced than those for men. However, women's desire for upward mobility is constrained by the continuing presence of gender "essentialist" views which hold men and women to be inherently, categorically different in terms of preferences and aptitudes (Hollander \& Howard 2000). Essentialism pushes women toward jobs traditionally done by women, such as teaching, nursing, and other care-related service work - while men under the influence of essentialism prefer to stay in male-dominate fields. In England's view, it may be women with higher earning potential - especially those whose parents and themselves went to college - who more often seek to integrate male-dominated jobs; for them, upward mobility may require crossing the gender line. On the other hand, women with less access to high-status jobs can pursue an upwardly-mobile path that includes female-dominated work; for them, getting into a white-collar administrative job, nursing career or teaching credential represents upward mobility even though their destination career is still female-dominated. As a result, gender integration has advanced much more among higher-status occupations.

England's explanation fits the historical pattern described by Cotter et al. (2004), in which the bulk of gender segregation has occurred among workers with at least a college degree. However, a simpler explanation results from the fact that women's education college completion rates have risen much faster than men's. That means there are many more women with college degrees for employers to choose from. In contrast, the pool of workers without college degrees looking for work has skewed much less female, and there is little pressure to hire women for traditionally blue-collar jobs. From the employer's perspective, then, the supply of workers has become much more integrated at the high end of the occupational scale (Cohen 2007).

The role of women's preferences, and the socialization processes that produce them, is controversial and difficult to study (Correll 2001). Clearly, there is an element of choice or selection operating in the distribution of workers across occupations, beginning with childhood socialization and the educational aspirations of adolescents, and culminating in a series of contingent decisions that emerge over the life course of the individual (Jacobs 1989). When women - through choice or necessity - prioritize family obligations over paid employment, the consequences with regard to time and labor force experience lost are irreversible (Polachek 1981).

Our understanding of these dynamics is hampered because data are usually only recorded for people who already have obtained the jobs in the question (Fernandez and Mors 2008). Current occupations cannot be said to measure mere occupational "choices," but must rather represent the outcome of interactions among both workers and employers (not to mention teachers, parents, peers and other involved agents). Nevertheless, even among those attending college, both men and women continue to pursue gender-typed courses of study, ironically exercising their growing freedoms in ways that reinforce traditional gender divisions and stall occupational 
integration. As a result, gender segregation across professional fields remains strong, whether indicated by areas of study (Charles \& Bradley 2009) or professional specialization (Ku 2011).

Identifying the causes of segregation is further complicated by the distinction between two different kinds of gender segregation (Charles \& Grusky 2004): that which is a more benign division between comparably-rewarded manual versus non-manual tasks, or "horizontal" segregation; and that which involves separation into hierarchically ranked occupations within those spheres, or "vertical" segregation. In practice, this differentiation is very difficult to define, sometimes resulting in circular definitions in which what men do is perceived as more "manual" and also higher status than what women do. In any event, this scheme at least attempts to address the fact that segregation results from a combination of both culturally-based "choices" and hierarchically imposed status rankings.

\section{Economic transformation}

Transformation in the U.S. economy has had paradoxical effects on gender integration. On the one hand, growth in the service economy has commodified many of the unpaid tasks historically performed by women in their homes, especially in the areas of health, childcare, education, and food services (Cotter et al. 2001). This has created massive employment opportunities in areas that are culturally tilted toward women's work. Thus, millions of women have shifted their energies from the unpaid workplace at home toward the paid workplace, where work for pay provides independence (from family) but also creates dependence (on the market) - even as it helps to break down society's gender division of labor (Thistle 2006).

On the other hand, however, the expanding service sector has also created "occupational ghettos" (Charles and Grusky 2004), where high concentrations of women perform labor associated with their historical family roles. In fact, much of the growth in employment opportunity for women has been in segregated occupations. Nevertheless, the overall effect of moving women's labor away from households and towards the paid economy has been in the direction of desegregating the labor force (Cohen 2004).

\section{Employer practices}

Employer discrimination against women in hiring and promotion places some men and women in different jobs (Tomaskovic-Devey \& Stainback 2012). Some discrimination is overt and intentional, while other practices are the result of unconscious biases and stereotypes (Ridgeway 2011). Although the overall contribution of such practices to the observed level of segregation is hard to measure, by looking at various characteristics of workplaces and their management practices, we can at least gain a better understanding of the social mechanisms at work (Kalev 2009). 
One form of discrimination - known as "statistical discrimination” - is based on the employers' expectations or assumptions about how workers will perform based on the groups to which they belong (Pager \& Karafin 2009). For example, hiring managers may assume that female employees will take maternity leaves, or move away if their husbands get better job offers elsewhere. Such assumptions - although often or even usually incorrect - can be powerful drivers of decisions because managers must act on limited information about potential workers (Bielby \& Baron 1986).

One recurring theme in this research is the role of bureaucratic or formalized employment practices, especially in hiring (Kmec, McDonald and Trimble 2010). Replacing discretion by individual managers with formal human resource practices has been shown to reduce gender segregation in some cases. On the other hand, formal rules also may be a "smokescreen," hiding traditional sexist practices (for a review see Baron et al. 2007). Clearly, larger employers are under greater legal and regulatory scrutiny, and may be more successfully pressured to implement gender-equity practices, especially by the threat of law suits. However, Bergman (2011) points out that government anti-discrimination efforts have put more pressure on employers of professional workers than those who hire blue collar workers. And civil litigation to confront gender discrimination requires money and other resources that are more available to professional women. In contrast, while women's college completion rates have increased, women's access to the training required for work in the non-college skilled trades - carpentry and plumbing, for example - has been much more restricted.

Another line of research has examined the role of managers as motivated actors in the gender segregation regime, whose choices and actions may be driven by their own gender and related experiences. Following this insight, we find that the gender of managers affects segregation, as workplaces with more women in positions of authority also exhibit higher levels of integration (Huffman, Cohen and Pearlman 2010). This heightens the importance of integrating managerial jobs, because such access for women may be a prerequisite for more widespread desegregation (Cohen, Huffman and Knauer 2009; Reskin and McBrier 2000).

\section{What are the consequences of segregation?}

The most-studied effect of occupational segregation is its contribution to the gender wage gap (Shauman 2006). However, the sorting of men and women into different jobs has a variety of consequences, including job satisfaction and stress as well as employee turnover (Reskin, McBrier \& Kmec 1999). Because wages are more easily measured and compared across work settings - both for researchers and for workers comparing job opportunities and outcomes focusing on the wage gap is both substantively and methodologically reasonable. 
The gender wage gap could result from three mechanisms. First, if women earn less than men on average, then it follows that female-dominated occupations will have lower average pay. That is true, but it does not account for the entire effect of gender composition; even statistically holding constant the lower wages of women, average pay is smaller in jobs with more women in them (Cohen and Huffman 2003a). Second, women may be sorted into jobs that have lower expected earnings. That could result from employers' hiring practices (Fernandez and Mors 2008), from women's lower levels of skills and experience (England, Hermsen and Cotter 2000), or from women's acting on their own occupational "preferences," such as the need to choose flexible jobs so they can care for family members (Cha 2013; England 2005).

All of these processes do contribute to the tendency of women to cluster in jobs that pay less than men's, or to specialize in lower-paid areas within their fields (Boulis \& Jacobs 2008). However, a third mechanism is particularly revealing about the deeply embedded nature of gender in modern society: devaluation (Reskin 1988). Occupational gender devaluation occurs when occupations with high concentrations of women are paid less because women disproportionately fill them. That results from a number of factors which are difficult to differentiate in a study, such as the greater power of men to protect their own privileges in the workplace, and the discriminatory practices of managers and employers who profit from paying women less. However, recent research, which carefully sequences the changes in occupational composition and earnings over time, provides strong evidence that average pay in occupations does in fact decline after women enter them (Levanon, England and Allison 2009). Further research is needed to help further understand this process.

The structural nature of devaluation is underscored by the finding that in labor markets (such as cities or metropolitan areas) with relatively higher levels of segregation, women's earnings are lower regardless of the gender composition of their own jobs (Cotter et al. 1997; Cohen and Huffman 2003b). That is, it is worse to work in a female-dominated job in a labor market where the segregation level is high than it is to work in the same job in a more integrated market. And in workplaces with greater task segregation between men and women, women appear less likely to advance into management positions (Kalev 2009). We might speculate that this pattern occurs either because segregation allows different kinds of labor to be more thoroughly associated with one gender versus another, or because segregation strengthens men's hand in shaping outcomes to their ends. In any event, the pattern is pervasive and important, and remains a fruitful area for future research.

\section{Where are we going from here?}

After the rapid pace of desegregation in the 1970s and 1980s, it became common to assume integration was inevitable (Cotter, Hersen \& Vanneman 2011). In his book Destined for Equality (1998), for example, Robert Max Jackson describes the tension between men's power and the 
growing rationalization of economic organizations, which makes gender segregation impractical or unprofitable - because it retards the development of workers arbitrarily. Rationalization is essential for competition, and eventually, in Jackson's view, it would overwhelm men's desire or ability to maintain their own power as men. Now, the stalled progress of gender equality's march has undermined its aura of inevitability (England 2010).

Whether or not gender integration will eventually regain momentum, there are reasons to be doubtful about such a change in the immediate future. First, consider the role of higher education. Women now earn more college degrees than men, representing a reversal of longstanding inequality (DiPrete \& Buchmann 2013; Goldin, Katz \& Kuziemko 2006). However, the fields of study remain highly segregated between men and women, and that segregation even increased in the last decade (England 2010). By my calculation, using the same index of dissimilarity measure I used above, with data from the National Center for Education Statistics (2011), the segregation of male and female bachelor's degree recipients, after falling until the 1990s was flat and then rose slightly in the last decade, to $29.2 \%$ in 2008-09. Specifically, some of the most common majors for women in college are in the health and clinical sciences, where $85 \%$ of the graduates are women. On the other hand, engineering-related majors are among the most common for men, and these are $84 \%$ male. Even if women continue to increase their advantage in overall graduation rates, therefore, if men and women do not increase their overlap in fields of study, educational attainment alone may not trigger more reduction in occupational segregation.

Second, consider the role of cultural attitudes. An important basis for change is in attitudes toward the work that men and women should do, and what they want to do. And here, too, there is a stall in the long-term trend toward egalitarianism. In an analysis of attitudes toward women's work, parenting, education and roles in politics, Cotter et al. (2011) argue that, although the ideal of gender egalitarianism has become popular in the U.S., it occurs simultaneously with a newly valorized view of motherhood. The result is a rising frame of "egalitarian essentialism, combining support for stay-at-home mothering with a continued feminist rhetoric of choice and equality" (Cotter et al. 2011:261). In this context, in which freely-chosen "traditional” roles for women are culturally celebrated, it is not surprising that occupational segregation shows little if any movement toward equality (Ridgeway 2011).

Finally, there is the possibility of state intervention. Since the passage of the Civil Rights Act in 1964, there have been two principal mechanisms by which the government has influenced the level of occupational segregation as a form of gender inequality. One way is through the legal system and the courts, to enforce anti-discrimination laws; the other is by setting standards for employment at government agencies and the private companies that have government contracts (Hirsh 2009; Kalev and Dobbin 2006). In actuality, both of these mechanisms have been weak, especially since the mid-1980s. In the absence of blatant, provable discrimination, most employers have been free to hire and promote men and women into different positions with little fear of legal or regulatory consequences (Tomaskovic-Devey \& Stainback 2012). One recent 
study concludes that anti-discrimination law in the U.S. is "a system whose symbolic presence is more powerful and pervasive than its practical effect” (Nielsen and Nelson 2008).

Despite the pessimism of this conclusion, in the realms of education, cultural attitudes and state intervention there remains the potential - at present unrealized - for renewed movement toward gender integration. Any one of these areas might provide impetus for change in the others - for example, shifting cultural attitudes (and political pressure) could spark a change in government policies. But the evidence to date does not clearly show what combination of forces necessary to reduce occupational gender segregation might arise in the future. 


\section{References}

Baron, J.N., Hannan, M.T., Hsu, G. \& Kocak, O. 2007, "In the company of women: Gender inequality and the logic of bureaucracy in start-up firms", Work and Occupations, vol. 34, no. 1 , pp. 35-66.

Bergmann, B.R. 2011, "Sex Segregation In The Blue-Collar Occupations: Women's Choices Or Unremedied Discrimination? Comment on England", Gender \& Society, vol. 25, no. 1, pp. 88-93.

Bielby, William T. and James N. Baron. 1986. "Men and Women at Work: Sex Segregation and Statistical Discrimination.” American Journal of Sociology 91(4):759-799.

Boulis, Ann K. and Jerry A. Jacobs. 2008. The Changing Face of Medicine: Women Doctors and the Evolution of Health Care in America. Ithaca and London: ILR Press.

Bridges, William P. 2003. "Rethinking Gender Segregation and Gender Inequality: Measures and Meanings.” Demography 40(3):543-568.

Cha, Youngjoo. 2013. "Overwork and the Persistence of Gender Segregation in Occupations." Gender \& Society 27(April):158-184.

Charles, M. \& Bradley, K. 2009, "Indulging Our Gendered Selves? Sex Segregation by Field of Study in 44 Countries", American Journal of Sociology, vol. 114, no. 4, pp. 924-976.

Charles, Maria \& David B. Grusky. 2004, Occupational ghettos: The worldwide segregation of women and men, Stanford University Press, Stanford, California :.

Charles, Maria and David B. Grusky. 1995. "Models for Describing the Underlying Structure of Sex Segregation.” American Journal of Sociology 100(4):931-971.

Cohen, P.N. 2007, “Confronting Economic Gender Inequality”, Review of Radical Political Economics, vol. 39, no. 1. Pp. 132-137.

Cohen, P.N. 2004, "The Gender Division of Labor: 'Keeping House' and Occupational Segregation in the United States", Gender \& Society, vol. 18, no. 2, pp. 239-252.

Cohen, P.N. \& Huffman, M.L. 2007, "Working for the woman? Female managers and the gender wage gap", American Sociological Review, vol. 72, no. 5, pp. 681-704.

Cohen, P.N., Huffman, M.L. \& Knauer, S. 2009, "Stalled Progress? Gender Segregation and Wage Inequality Among Managers, 1980-2000", Work and Occupations, vol. 36, no. 4, pp. 318-342.

Cohen, P. \& Huffman, M. 2003a, "Individuals, jobs, and labor markets: The devaluation of women's work", American Sociological Review, vol. 68, no. 3, pp. 443-463. 
Cohen, P. \& Huffman, M. 2003b, "Occupational segregation and the devaluation of women's work across US labor markets", Social Forces, vol. 81, no. 3, pp. 881-908.

Correll, Shelley J. 2001. "Gender and the Career Choice Process: The Role of Biased SelfAssessments.” American Journal of Sociology 106(6):1691-1730.

Cotter, D.A., Defiore, J., Hermsen, J.M., Kowalewski, B.M. \& Vanneman, R. 1998, "The Demand for Female Labor", American Journal of Sociology, vol. 103, no. 6, pp. 1673-1712.

Cotter, D.A., Defiore, J.A., Hermsen, J.M., Kowalewski, B.M. \& Vanneman, R. 1997, "All Women Benefit: the Macro-Level Effect of Occupational Integration on Gender Earnings Equality", American Sociological Review, vol. 62, no. 5, pp. 714-734.

Cotter, D.A., Hermsen, J.M. \& Vanneman, R. 2001, "Women's Work and Working Women: The Demand for Female Labor", Gender \& Society, vol. 15, no. 3, pp. 429-452.

Cotter, D., Hermsen, J.M. \& Vanneman, R. 2011, "The End of the Gender Revolution? Gender Role Attitudes from 1977 to 2008", American Journal of Sociology, vol. 117, no. 1, pp. pp. 259-289.

Diprete, Thomas A and Claudia Buchmann. 2013. The Rise of Women: The Growing Gender Gap in Education and What It Means for American Schools. New York: Russell Sage Foundation.

Duncan, Otis Dudley and Beverly Duncan. 1955. "A Methodological Analysis of Segregation Indexes.” American Sociological Review 20(2):210-217.

England, P. 2005, "Gender inequality in labor markets: The role of motherhood and segregation", Social Politics, vol. 12, no. 2, pp. 264-288.

England, P., Hermsen, J.M. \& Cotter, D.A. 2000, "The devaluation of women's work: A comment on Tam", American Journal of Sociology, vol. 105, no. 6, pp. 1741-1751.

England, P. 2010, "The Gender Revolution: Uneven and Stalled", Gender Society, vol. 24, no. 2, pp. 149-166.

Fernandez, R.M. \& Mors, M.L. 2008, "Competing for jobs: Labor queues and gender sorting in the hiring process", Social science research, vol. 37, no. 4, pp. 1061-1080.

Geist, C. \& Cohen, P.N. 2011, "Headed Toward Equality? Housework Change in Comparative Perspective", Journal of Marriage and Family, vol. 73, no. 4, pp. 832-844.

Goldin, C., Katz, L.F. \& Kuziemko, I. 2006, "The Homecoming of American College Women: The Reversal of the College Gender Gap", The Journal of Economic Perspectives, vol. 20, no. 4, pp. pp. 133-156. 
Hirsh, C.E. 2009, "The Strength of Weak Enforcement: The Impact of Discrimination Charges, Legal Environments, and Organizational Conditions on Workplace Segregation", American Sociological Review, vol. 74, no. 2, pp. 245-271.

Hollander, Jocelyn A. and Judith A. Howard. 2000. "Social Psychological Theories on Social Inequalities.” Social Psychology Quarterly 63(4):338-351.

Huffman, M.L., Cohen, P.N. \& Pearlman, J. 2010, "Engendering Change: Organizational Dynamics and Workplace Gender Desegregation, 1975-2005", Administrative Science Quarterly, vol. 55, no. 2, pp. 255-277.

Jacobs, Jerry A. 1989. Revolving Doors: Sex Segregation and Women's Careers. Stanford, California: Stanford University Press.

Kalev, A. 2009, "Cracking the Glass Cages? Restructuring and Ascriptive Inequality at Work", American Journal of Sociology, vol. 114, no. 6, pp. 1591-1643.

Kalev, A. \& Dobbin, F. 2006, "Enforcement of civil rights law in private workplaces: The effects of compliance reviews and lawsuits over time", Law and Social Inquiry-Journal of the American Bar Foundation, vol. 31, no. 4, pp. 855-903.

Kay, Fiona and Elizabeth Gorman. 2008. "Women in the Legal Profession.” Annual Review of Law and Society. 4:299-332.

Kmec, J.A., McDonald, S. \& Trimble, L.B. 2010, "Making Gender Fit And "Correcting" Gender Misfits: Sex Segregated Employment and the Nonsearch Process", Gender \& Society, vol. 24, no. 2, pp. 213-236.

Ku, M.C. 2011, "When Does Gender Matter?: Gender Differences in Specialty Choice Among Physicians", Work and Occupations, vol. 38, no. 2, pp. 221-262.

Levanon, A., England, P. \& Allison, P. 2009, "Occupational Feminization and Pay: Assessing Causal Dynamics Using 1950-2000 US Census Data", Social Forces, vol. 88, no. 2, pp. 865891.

McTague, T., Stainback, K. \& Tomaskovic-Devey, D. 2009, "An Organizational Approach to Understanding Sex and Race Segregation in US Workplaces", Social Forces, vol. 87, no. 3, pp. 1499-1527.

National Center for Education Statistics. 2010. Digest of Education Statistics. http://nces.ed.gov/programs/digest/. Accessed October 24, 2011.

Nielsen, L.B. \& Nelson, R.L. 2008, "Scaling the Pyramid: A Sociolegal Model of Employment Discrimination Litigation" in Handbook of Employment Discrimination Research, eds. L.B. Nielsen \& R.L. Nelson, Springer New York, , pp. 3-34. 
Pager, Devah and Diana Karafin. 2009. "Bayesian Bigot? Statistical Discrimination, Stereotypes, and Employer Decision Making.” Annals of the American Academy of Political and Social Science 621(January):70-93.

Polachek, Solomon William. 1981. “Occupational Self-Selection: A Human Capital Approach to Sex Differences in Occupational Structure.” Review of Economics and Statistics 63(1):6069.

Reskin, B.F. 1988, "Bringing the Men Back in: Sex Differentiation and the Devaluation of Women's Work", Gender and Society, vol. 2, no. 1, pp. pp. 58-81.

Reskin, B.F. \& McBrier, D.B. 2000, "Why not ascription? Organizations' employment of male and female managers", American Sociological Review, vol. 65, no. 2, pp. 210-233.

Reskin, Barbara F., Debra B. McBrier and Julie A. Kmec. 1999. “The Determinants and Consequences of Workplace Sex and Race Composition.” Annual Review of Sociology 25:335-361.

Ridgeway, Cecilia L. 2011. Framed By Gender: How Gender Inequality Persists in the Modern World. New York: Oxford University Press.

Rotolo, T. \& Wilson, J. 2007, "Sex segregation in volunteer work", Sociological Quarterly, vol. 48, no. 3, pp. 559-585.

Shauman, K.A. 2006, "Occupational sex segregation and the earnings of occupations: What causes the link among college-educated workers?", Social science research, vol. 35, no. 3, pp. 577-619.

Stainback, K., Tomaskovic-Devey, D. \& Skaggs, S. 2010, "Organizational Approaches to Inequality: Inertia, Relative Power, and Environments", Annual Review of Sociology, Vol 36, vol. 36, pp. 225-247.

Taylor, C.J. 2010, "Occupational Sex Composition and the Gendered Availability of Workplace Support", Gender \& Society, vol. 24, no. 2, pp. 189-212.

Thistle, S. 2006, From marriage to the market: the transformation of women's lives and work, University of California Press, Berkeley.

Tomaskovic-Devey, Donald and Kevin Stainback. 2012. Documenting Desegregation. Racial and Gender Segregation in Private-Sector Employment Since the Civil Rights Act. New York: Russell Sage Foundation.

Tomaskovic-Devey, Donald, Cathy Zimmer, Kevin Stainback, C. Robinson, T. Taylor, \& T. McTague. 2006, "Documenting desegregation: Segregation in American workplaces by race, ethnicity, and sex, 1966-2003", American Sociological Review 71(4):565-588. 
Yaish, M. \& Stier, H. 2009, "Gender Inequality in Job Authority: A Cross-National Comparison of 26 Countries", Work and Occupations, vol. 36, no. 4, pp. 343-366.

Weinberg, D. H. 2004, "Evidence From Census 2000 About Earnings by Detailed Occupation for Men and Women”, Census 2000 Special Reports, May 2004. 
TABLE 1

Gender composition and median earnings of the 25 largest occupations

\begin{tabular}{|c|c|c|c|c|c|c|c|}
\hline & \multicolumn{2}{|c|}{ Number of workers } & \multicolumn{2}{|c|}{$\begin{array}{c}\text { Gender } \\
\text { composition }\end{array}$} & \multicolumn{3}{|c|}{ Median earnings } \\
\hline & Men & Women & $\begin{array}{l}\text { Percent } \\
\text { male }\end{array}$ & $\begin{array}{l}\text { Percent } \\
\text { female }\end{array}$ & Men's & Women's & $\begin{array}{c}\text { Women's } \\
\text { as \% of } \\
\text { men's }\end{array}$ \\
\hline Secretaries and administrative assistants & 111,126 & $2,391,057$ & 4.4 & 95.6 & 34,584 & 34,304 & 99.2 \\
\hline Registered nurses & 195,969 & $1,703,779$ & 10.3 & 89.7 & 61,438 & 61,184 & 99.6 \\
\hline Bookkeeping, accounting, and auditing clerks & 109,925 & 807,909 & 12.0 & 88.0 & 35,186 & 34,731 & 98.7 \\
\hline Nursing, psychiatric, and home health aides & 177,628 & $1,121,650$ & 13.7 & 86.3 & 25,071 & 24,587 & 98.1 \\
\hline Elementary and middle school teachers & 483,966 & $1,717,323$ & 22.0 & 78.0 & 48,659 & 47,379 & 97.4 \\
\hline Cashiers & 302,920 & 747,572 & 28.8 & 71.2 & 19,790 & 18,947 & 95.7 \\
\hline Customer service representatives & 466,395 & 992,085 & 32.0 & 68.0 & 31,373 & 30,614 & 97.6 \\
\hline First-line supervisors of office and admin. support workers & 439,828 & 730,318 & 37.6 & 62.4 & 44,780 & 41,435 & 92.5 \\
\hline Accountants and auditors & 678,697 & 957,553 & 41.5 & 58.5 & 59,243 & 51,680 & 87.2 \\
\hline Financial managers & 454,493 & 506,684 & 47.3 & 52.7 & 65,572 & 53,095 & 81.0 \\
\hline First-line supervisors of retail sales workers & $1,442,456$ & $1,044,972$ & 58.0 & 42.0 & 37,475 & 31,152 & 83.1 \\
\hline Retail salespersons & $1,016,234$ & 650,403 & 61.0 & 39.0 & 30,981 & 24,560 & 79.3 \\
\hline Cooks & 660,434 & 391,462 & 62.8 & 37.2 & 19,663 & 17,717 & 90.1 \\
\hline Stock clerks and order fillers & 503,029 & 291,530 & 63.3 & 36.7 & 25,965 & 25,171 & 96.9 \\
\hline Managers, miscellaneous & $1,768,367$ & 853,914 & 67.4 & 32.6 & 70,998 & 59,366 & 83.6 \\
\hline Lawyers & 558,684 & 247,471 & 69.3 & 30.7 & 113,373 & 100,704 & 88.8 \\
\hline General and operations managers & 597,151 & 242,891 & 71.1 & 28.9 & 70,732 & 57,464 & 81.2 \\
\hline Production workers, miscellaneous & 617,517 & 231,433 & 72.7 & 27.3 & 31,639 & 25,919 & 81.9 \\
\hline First-line supervisors of non-retail sales workers & 735,355 & 273,982 & 72.9 & 27.1 & 55,417 & 50,217 & 90.6 \\
\hline Janitors and building cleaners & $1,078,987$ & 367,004 & 74.6 & 25.4 & 26,105 & 20,957 & 80.3 \\
\hline Sales representatives, wholesale and manufacturing & 868,685 & 280,562 & 75.6 & 24.4 & 60,245 & 50,408 & 83.7 \\
\hline Chief executives & 710,054 & 196,479 & 78.3 & 21.7 & 107,250 & 87,093 & 81.2 \\
\hline Laborers and freight, stock, and material movers, hand & 940,687 & 187,899 & 83.4 & 16.6 & 29,091 & 24,961 & 85.8 \\
\hline Driver/sales workers and truck drivers & $2,077,567$ & 86,605 & 96.0 & 4.0 & 38,396 & 29,699 & 77.3 \\
\hline Construction laborers & 791,591 & 19,105 & 97.6 & 2.4 & 30,853 & 28,600 & 92.7 \\
\hline
\end{tabular}

Note: Full-time, year-round workers. Source: U.S. Census Bureau, 2010 American Community Survey. 